\title{
Research and management strategies for major tree diseases in Canada: Synthesis Part 1
}

\author{
by Pritam Singh ${ }^{1}$
}

Forests are diverse and complex associations of plant and animal life that are influenced considerably by their environment and man, and by their interactions. Forest pests, including pathogens, form an important component of the forest ecosystem, and their management is an integral part of forest management. There is, however, a need to obtain a better understanding of these pests, and their relationships with plants and other factors in the environment.

This article attempts to compile most of the available information about research on major tree diseases in Canada, particularly that which deals with or has led to the development of strategies to control or manage those diseases. A brief information on Canada's forest resource and the losses caused by these diseases and by other damage problems is also included.

Key words: forests, tree diseases, research strategies, disease management strategies, disease losses, integrated pest management.
Les forêts sont des associations diverses et complexes de plantes et d'animaux qui sont influencées considérablement par leur environnement et l'homme, et par leurs interactions. Les ravageurs forestiers, $\mathrm{y}$ compris les pathogènes, forment une composante importante de l'écosystème forestier, et le contrôle des ravageurs constitue un élément intégral de l'aménagement forestier. Toutefois, il est nécessaire d'obtenir une meilleure compréhension de ces ravageurs, et de leurs relations avec les plantes et les autres facteurs de l'environnement.

Cet article tente de compiler la majeure partie de l'information disponible sur la recherche effectuée sur les principales maladies des arbres au Canada, particulièment celle qui traite ou qui a mené à l'élaboration des stratégies de contrôle ou de gestion de ces maladies. Une brève indication des ressources forestières du Canada et des pertes provoquées par ces maladies ainsi que par d'autres causes de dégat est également illustrée.

Mots cles: forêts, maladies des arbres, stratégies de recherche, stratégies de contrôle des maladies, pertes causées par les maladies, aménagement intégré des ravageurs.

\section{Introduction}

The forests of Canada are in a transition, from natural forests to intensively managed plantations, from an era of overabundance to a period of tighter wood supplies. Along with this change, has evolved the necessity of managing this resource so that it is economically viable and ecologically sustainable.

Management of forests in Canada is a provincial responsibility because most of the forest land is owned by provincial governments. Broadly speaking this responsibility includes renewal, protection, harvesting, and commercialization of forests. Forest protection includes management of pests, which in turn covers prevention or control of insects and diseases.

Over the years, with evolution in the philosophy of forest management, the concept of protecting forests have also changed from crisis management of pest outbreaks, usually aimed at eradication to effective long-term management of the pest. Forest protection, including management of forest diseases, is now considered not only an important element but an integral part of forest management, using both classical methods and frontier technological strategies. These include manipulating the biological system(s) of a pathogen or of a host to obtain a situation in which the pathogen will co-exist but will not cause any apparent damage or loss in yield. The Canadian Council of Forest Ministers (1987), while endorsing a National Forest Sector Strategy, remarked

${ }^{1}$ Forestry Canada, Science and Sustainable Development Directorate, Place Vincent Massey - 21st Floor, 351 St. Joseph Blvd., Hull, Quebec, Canada K1A $1 \mathrm{G} 5$.

Part 2 will be published in the June 1993 issue.

that "failure to invest in protection will jeopardize future benefits from the forest. Furthermore, the level of protection should be appropriate to the value of the resource and the level of investment in its management.' The Canadian Institute of Forestry (1989), while supporting the forest protection recommendations of the National Forest Sector Strategy, emphasized the need to integrate forest management with environmentally safe pest control measures.

This paper compiles most of the currently available information on the major Canadian tree diseases where management strategies have been or are being developed, and where such strategies have influenced or have the potential to influence general forest management practices. It also includes some background information on Canada's forest resources and the losses caused by diseases, and some future directions for research and management of tree diseases.

\section{Canada's Forest Resource and Losses Caused by Tree Diseases}

Forest Resource ${ }^{2}$

Canada, the second largest country in the world, has an area of 997 million $\mathrm{km}^{2}$, of which 453 million ha are covered by forests, representing $10 \%$ of the world's forested land and $45 \%$ of our country's total land-mass (Table 1). Approximately 398 million ha are inventoried and about 244 million ha are productive and capable of sustaining growth, with an allowable annual harvest of 177 million $\mathrm{m}^{3}$

\footnotetext{
${ }^{2}$ Most of the statistics on forests and forest products were obtained from Forestry Canada's Forestry Facts 1990 and 1991, and Canada's Forest Indus-
} tries 1986 DataBook. 
Table 1. Forest resources of Canada

\begin{tabular}{|c|c|c|}
\hline \multirow[t]{3}{*}{ Forest cover } & 453 & $\begin{array}{l}\text { Million hectares [ }=10 \% \text { of world's } \\
\text { forested land and } 45 \% \text { of Canada's land] }\end{array}$ \\
\hline & 398 & Million hectares is inventoried \\
\hline & 244 & Million hectares is productive \\
\hline $\begin{array}{l}\text { Allowable } \\
\text { annual harvest }\end{array}$ & 177 & Million $\mathrm{m}^{3}$ \\
\hline $\begin{array}{l}\text { Total forest } \\
\text { resource wood } \\
\text { volume }\end{array}$ & 23 & $\begin{array}{l}\text { Billion } \mathrm{m}^{3} \text { [ } 77 \% \text { is softwood and } 23 \% \text { is } \\
\text { hardwood] }\end{array}$ \\
\hline \multirow[t]{8}{*}{ Production } & $24 \%$ & of total world forest products \\
\hline & $16 \%$ & $\begin{array}{l}\text { of total world softwood timber production } \\
\text { [3rd after the former USSR and USA] }\end{array}$ \\
\hline & $15 \%$ & $\begin{array}{l}\text { of total world coniferous harvest of indus- } \\
\text { trial roundwood }\end{array}$ \\
\hline & $5 \%$ & of world output of panel products \\
\hline & $2 \%$ & of world volume of hardwood fibre \\
\hline & $16 \%$ & of world pulp and paper output \\
\hline & $7 \%$ & of all paper and paper board output \\
\hline & $32 \%$ & $\begin{array}{l}\text { of total world's newsprint output (no. } 1 \text { in } \\
\text { the world) }\end{array}$ \\
\hline $\begin{array}{l}\text { Canadian } \\
\text { forest industry }\end{array}$ & $\$ 35$ & $\begin{array}{l}\text { Billion industry: employs approx. } 840,000 \\
\text { persons }\end{array}$ \\
\hline
\end{tabular}

${ }^{1}$ Most figures obtained from Forestry Facts 1990, 1991, For. Can. Ottawa.

(Forestry Canada 1990). The total forest resource contains a wood volume of about 23 billion $\mathrm{m}^{3}$ of which $77 \%$ is coniferous and $23 \%$ deciduous; $6 \%$ overmature, $40 \%$ mature, $37 \%$ immature, $6 \%$ regeneration, and $11 \%$ is unclassified. Canada's forest products account for almost $24 \%$ of total world production: lumber 45 million $\mathrm{m}^{3}$, wood pulp 5 million $\mathrm{t}$, and paper and paperboard 13 million $\mathrm{t}$; that is more than $12 \%$ of manufactured goods.

The Canadian forest and forest products industry are vital to the country's economic prosperity with about $\$ 35$ billion worth of products annually. In 1987 the forest industry produced $\$ 38.3$ billion worth of goods with a net foreign exchange of $\$ 18.3$ billion, a contribution to Canada's economy greater than the combined earnings of agriculture, fisheries, mining, and fuels (Canadian Institute of Forestry 1989). It also provides direct and indirect employment for about 840,000 Canadians (Lachance 1990). In addition forests are the backdrop for multi-billion dollar tourist and outdoor recreation industries. Other details on Canadian forest products statistics in relation to world production are given in Table 1.

\section{Losses caused by Diseases}

Forest pathogens are a natural part of the forest ecosystem and in fact a large number of them may not cause any serious damage. However, there are many which do cause significant losses. Dramatic outbreaks of native pathogens have occurred in both mature and immature forests, and some disease epidemics have occurred in tree nurseries and regenerations. Fungal infection of trees, unseasoned lumber and pulpwood chips continue to plague the Canadian forest sector.

Tree diseases induce losses through tree mortality; decay; cull, defects and deformation; reduction in growth; and predisposition to windthrow or to other pests. Other losses caused indirectly by tree diseases include delayed regeneration, reduced stock, changes in stand composition, erosion in site quality, reduced management options, and economic
Table 2. Comparison of annual forest productivity and losses due to insects, diseases and fires ${ }^{1}$

\begin{tabular}{lc}
\hline & $\begin{array}{c}\text { Volume } \\
\text { (millions of } \\
\mathrm{m}^{3} \text { per year) }\end{array}$ \\
\hline Canada's annual cut (1986) & 177 \\
Annual losses to major diseases (1982-86 average) & 45 \\
Annual losses to major insects (1982-86 average) & 63 \\
Annual area burned by fire (1989 data) 7.1 million ha & \\
\hline
\end{tabular}

${ }^{1}$ Forestry Facts 1990, For. Can., Ottawa, 87 p.

losses due to the necessity of replacing lost stock and special management practices that need to be adopted.

Quantifying these losses is often difficult, and calculating their dollar values even more so. However, it is generally accepted that insects and diseases cause substantial forest losses. Current annual losses are reported in cubic meters of wood, with no dollar value assigned (Tables 2,3 ). It is also suggested that for every two trees harvested, one additional tree is lost to insects or diseases. In very general terms, annual timber loss due to insects and diseases in Canada is estimated to be equivalent to the timber used to build more than one million homes.

In the early 1970s annual losses due to diseases in Canada were estimated at about 27.1 million $\mathrm{m}^{3}$; these losses were mostly attributed to tree mortality and did not include losses due to reduced growth, delayed regeneration or reduced stocking. In 1976 these estimates increased to 40.4 million $\mathrm{m}^{3}$, but these figures included losses due to reduction in growth, tree mortality and destruction of wood; many of these losses were obtained from old-growth stands (Table 3). Major contributors to the 1976 estimates were trunk rots, root rots, dwarf mistletoes, white pine blister rust, and Hypoxylon canker. These depletions did not, however, include seedling or young sapling mortality from damping off, Scleroderris canker, seedling root rot, or stem rusts, although losses due to delayed regeneration, reduced stocking, growth reduction, and deformation were considerable (Whitney et al. 1983). Losses have not been quantified for many foliage or abiotic diseases, including frost damage, drought injury, sunscald, nutrient inbalance, and air pollution injuries, although these disease and damage problems are known to cause significant mortality, deformation and growth reduction in some situations (Rennie 1987). The ramifications of the effects of climate change on forest types and species distribution are not even fully realized.

\section{Major Disease Problems, and Research and Management Strategies}

Trees, like other living organisms, are subject to a variety of environmental stresses, injuries, and attack by insects and disease-inducing pathogens. Some of these stresses and injuries also make trees more vulnerable to further damage by other insects and diseases. Major diseases of forest and urban trees in Canada are summarized in Table 4 (Forest Insect and Disease Survey Reports 1980-1989); sometimes dramatic outbreaks of native pests have occurred in tree nurseries, and in immature and mature forests.

During the past 30 or so years, the subject of forest protection, including disease management, has become extremely important and exciting due to the advent of new concepts and technologies in forest and pest management, 
Table 3. Estimate of losses caused by major forest diseases in Canadian forest in $1976^{1}, 1981^{2}$ and $1987^{3}$ (millions $\mathrm{m}^{3}$ per year)

\begin{tabular}{|c|c|c|c|c|c|c|c|c|c|c|c|c|}
\hline & \multicolumn{3}{|c|}{ Mortality } & \multicolumn{3}{|c|}{ Growth destruction } & \multicolumn{3}{|c|}{ Wood destruction } & \multicolumn{3}{|c|}{ Total } \\
\hline & 1976 & 1981 & 1987 & 1976 & 1981 & 1987 & 1976 & 1981 & 1987 & 1976 & 1981 & 1987 \\
\hline Stem rots and decays & - & - & - & - & - & - & 24.8 & 25.0 & 25.0 & 24.8 & 25.0 & 25.0 \\
\hline Root rots & 1.7 & 12.0 & 7.7 & 3.4 & 7.7 & 12.2 & - & - & - & 5.1 & 19.7 & 19.9 \\
\hline Dwarf mistletoes & - & - & - & 4.7 & 3.8 & 3.5 & - & - & - & 4.7 & 3.5 & 3.5 \\
\hline Hypoxylon cankers & 3.8 & 11.2 & 11.2 & - & - & - & - & - & - & 3.8 & 11.2 & 11.2 \\
\hline White pine blister rust & 0.6 & - & - & - & - & - & - & - & - & 0.6 & - & - \\
\hline Miscellaneous & 0.3 & 4.9 & - & 1.1 & - & - & - & - & - & 1.4 & 4.9 & - \\
\hline Total & 6.4 & 28.1 & 18.9 & 9.2 & 11.5 & 15.7 & 24.8 & 25.0 & 25.0 & 40.4 & 64.6 & 59.6 \\
\hline
\end{tabular}

${ }^{1}$ Anonymous (1979).

${ }^{2}$ Personal communication.

${ }^{3}$ Brand (1991).

and because of the realization that forest protection is influenced by many other scientific disciplines. The pathogen or the parasite and the host form a complex host-parasite relationship, that needs to be understood in the forest ecosystem before we can develop strategies to prevent, control or manage disease and reduce losses. The need to obtain this understanding is increasing as forest inventories are being depleted. There is growing realization that new stands may not be able to cope with the demands of the forest market unless they are well-managed and well-protected.

Over the years Canadian forest pathologists have investigated some of the major tree diseases existing in both forest and urban conditions and developed strategies to prevent the onset or spread of disease epidemics and minimize losses (Table 4). These recommendations follow an integrated approach and include one or more of these measures: prevention applied directly by silvicultural means or preventive chemical or biological sprays; or indirectly by reducing logging injuries; avoiding silvicultural practices that may increase susceptibility to disease; eliminating cull or diseased, dying or dead trees through sanitation; altering species composition; and maintaining genetic diversity by using species that are best adapted to local climatic conditions, or those that are disease-resistant (Waters and Cowling 1976). Many of these recommendations have already been incorporated into management plans for different tree species (Table 4). Highlights of investigations on major tree diseases where control or management strategies are being researched, or are being used to control or manage disease problems, are discussed in the following pages.

\section{Root Diseases (Root Rots) \\ Disease Problem}

Root rots are perennial diseases of forest and urban trees (Singh 1989; Whitney 1988). Four major root rots, caused by four basidiomycetous fungi, are common in Canadian forests: Armillaria root rot, caused by Armillaria spp.; Fomes root rot, caused by Heterobasidion annosum (Fr.) Bref.; Laminated root rot, caused by Phellinus weirii (Murr.) Gilbn.; and Tomentosus root rot, caused by Inonotus tomentosus (Fr.) Gilbertson. These diseases cause decay in the roots, butt and stem of living trees and reduce timber volume by direct tree mortality, by reduction in growth, by inducing butt and stem cull, and by predisposing the affected trees to other pests and to windthrow, the latter through weakening of the root systems.
Table 4. List of major tree diseases where disease management strategies are in operation ${ }^{1}$

Armillaria root rot

Surveys and periodic monitoring, priority cutting and salvage, pre-establishment site treatment, inoculum reduction by stump removal or stump treatment following logging operation, selection of disease-free site, use of disease-free or diseaseresistant stock with well-developed root system, avoid bare-root stock and use container seedlings or direct seeding for susceptible upland sites, prevent or avoid injury or wounds to roots.

Laminated root rot Surveys and periodic monitoring, priority cutting and salvage, selection of disease-free site, inoculum reduction.

Tomentosus root rot Surveys and periodic monitoring, priority cutting and salvage, inoculum reduction, selection of disease-free site.

Fomes root rot Surveys and periodic monitoring, selection of clean and disease-free site, selection of non-susceptible host species, chemical treatment of stumps.

White pine blister rust

Surveys and periodic monitoring, follow hazard rating zones, sanitation through pruning and clipping of branches, sanitation near nurseries and seed orchards, use of disease-free and healthy sites and disease-resistant or disease-free stock, elimination of alternate host.

Western gall rust Surveys and periodic monitoring, sanitation and removal of infected branches or heavily infected trees, selection of clean and healthy site, use of resistant stock.

Scleroderris canker Selection of healthy and disease-free site, surveys and monitoring, sanitation and pruning, use of plant quarantine regulation where needed, avoid frost-susceptible sites, use of healthy and diseasefree or disease-resistant stock, fungicidal spray in nurseries and young plantations to control the North American strain of the fungus.

Dwarf mistletoe

Monitoring, sanitation, and use of clean and disease-free sites, prescribed burning, use of nonhost species, and good management practices.

Dutch elm disease Monitoring, sanitation and removal of dying and dead trees, chemical injections to root-flares, bark beetle control.

Stem decays More precise stand volume estimates needed, reduce rotation to avoid excessive loss from stem decays, salvage losses at various periods following tree death, prevent or avoid injuries or wounds by careful use of harvesting and pruning equipment.

Nursery diseases Monitoring, integrated approach including water management, sanitation and improved silvicultural practices in nurseries, preventive fungicide sprays, optimum storage and handling conditions.

${ }^{1}$ The table has been developed from Table 3 of Whitney et al. (1983). 
Root rots are the second most damaging disease problems of Canadian softwood and hardwood tree species in both plantations and natural stands. It is difficult to assess the impact of root rots, because often they kill trees which are already damaged or weakened by other unfavorable factors, such as environmental and site conditions, atmospheric pollutants, insects and other diseases. Estimates of annual losses caused by these diseases are believed to be more than 24 million $\mathrm{m}^{3}$, with more than 11 million $\mathrm{m}^{3}$ in Ontario (Whitney 1988, personal communication), and 10 million $\mathrm{m}^{3}$ in British Columbia (Forest Facts 1990). Their prevalence and severity varies from region to region, from site to site, and from stand to stand (Singh 1975, 1980, and 1981a,b,c; Whitney et al. 1983).

\section{Research and Management Strategies}

Management of root rots is difficult, partly because we do not fully understand the biology and behavior of the pathogens and epidemiology of the diseases, and partly because distribution of these diseases is in scattered patches, making it difficult to assess their true impact. In spite of these limitations, attempts are being made to manage some of these root diseases through an integrated approach, using ground cruising and aerial spotting to detect and evaluate distribution and impact of these diseases, forecasting through modelling and decision support systems, and application of silvicultural or chemical treatments, including chemical treatment of stumps, and modification of spacing, thinning and harvesting techniques. Considerable research has been conducted by several researchers in 1970s and 1980s in order to develop effective management strategies.

(a) In regeneration and young plantations - Singh (1975, 1980, and 1981a,b,c) reported that to avoid Armillaria root rot, trees should be kept healthy and protected from insect damage. If possible, sites with the least number of infected stumps should be selected for reforestation, and good sanitation should be practised in plantations, including removal of stumps prior to the establishment of new plantations; the latter can significantly reduce the source of inoculum.

Singh and Richardson (1973) recommended that Armillaria root rot can also be reduced significantly if plantations on susceptible sites can be established through seeding or container planting rather than by bare-root stock.

(b) In stands and managed plantations - Morrison (1981) and Whitney (1988) recommended specific measures for different phases of forest management: (i) Spacing phase - Spacing is not recommended in 15- to 20-year-old stands if there are 10 or more disease centers per hectare. However, if the disease centers are few and scattered, space normally except around disease centers. (ii) Commercial thinning phase - Only lightly infected stands may be thinned; heavily infected stands of commercial thinning age should not be thinned. In stands or parts of stands infested with Armillaria, partial cutting is discouraged to avoid further spread of the disease from small-diameter infected trees left behind during salvage. (iii) Final harvest and regeneration phase - This phase perhaps provides the best opportunity to control Armillaria root rot when a stand is harvested. The diseased trees should be marked prior to harvest, and the following management possibilities can be considered at final harvest: (a) Reduce the inoculum and sanitize the site by removing all stumps and roots within disease centers and from a 20-m strip around the centers. Also remove stumps and roots that contain the fungus and have a diameter larger than $5 \mathrm{~cm}$ and a length of $30 \mathrm{~cm}$, using a bulldozer fitted with a brush blade. (b) Slash burning may reduce the inoculum on the surface or within the surface layers of humus and stumps, but will not affect the fungus in the stumps and roots buried in soil; bark on the stump and on the roots, and the surrounding soil often prevent lethal temperatures from reaching the subterranean fungus in roots. (c) Planting of resistant or alternate species that are adapted to the site should be encouraged. Resistant provenance of white and Norway spruces and lodgepole pine should be used, and species such as balsam fir and poplars, which decay more easily than spruce, should be avoided. (d) On certain sites harvesting of merchantable volume and relying on natural regeneration may be the only possible option. (e) Root rot increases with the age of living trees, and in some situations cutting younger trees before the disease becomes a serious problem may be a primary method of managing the disease. Singh had also made this recommendation in 1980. (f) There is a direct relationship between site characteristics and the root rot incidence. Balsam fir and spruce tend to have more root rot on upland sites and on light-textured soils with low moisture regimes. Harvesting of higher and drier sites first and retaining trees on lowland sites for later harvesting can improve yield. Early harvest and conversion to other species is also recommended as one of the plausible strategies, particularly if the species are being repeatedly damaged by insects, making them more vulnerable to the disease. Forest managers are advised to harvest balsam fir as early as possible (40 to 50 years on upland sites) and to note that the least growth loss will be experienced on medium-density stands in moderately dry, heavy soils where root rot is least damaging to growth. $(g)$ Vigorous trees are less susceptible to root rots than non-vigorous trees. Intensive forest management techniques resulting in vigorous stands are the forest manager's primary defense against root rot.

(c) In intensively managed stands - In 1988 Whitney made recommendations for the management of root rots in intensively managed forest stands in his booklet, Hidden Enemy: (i) Harvesting: Whitney believes that harvesting machines and other partial cutting systems, such as wheeled skidders, increase the incidence of root rot through increased injury and root damage. Operator error, carelessness or ignorance may result in damage to trees near ground level and the resulting wound(s) provide entrance court(s) for the root rot fungi. Accordingly he recommended that a wellspaced skidded trail system be laid out before logging begins. Buffer trees left at critical points to absorb damage can be felled when the harvesting operation is complete. Directional felling and dropping of trees into natural openings can also reduce wounding. (ii) Site treatment and tending - Intensive site preparation and tending, especially in plantations, may increase the incidence of root rots. However, where root rots occur, infected dead material, especially stumps and buried roots, should be hauled out and exposed during site preparation. This will allow the uprooted material to dry, thus greatly reducing the potential inoculum of Armillaria and Annosus root rots. Sanitizing a site during its preparation and during intermediate cuttings through removal of dead materials reduces the potential for new infections of 
Armillaria root rot in all conifers, Tomentosus root rot in boreal spruce, and Annosus root rot in pine plantations. Commercial thinning operations may be suspended during the period of sap flow. (iii) Chemical treatment - Treating freshly cut stumps in plantations with Borax or $10 \%$ aqueous solution of zinc chloride reduces the incidence of Annosus root rot. Powdered Borax may be applied with a salt-shaker type container or a squeeze bottle, or painted on as a solution. Zinc chloride may, however, be applied with a pressure sprayer during commercial thinning operations (Morrison 1979). (iv) Stump removal - Annosus root rot fungus often enters through cut surfaces of the stumps and then spreads to other trees by direct root contact or root grafting. Control of this fungus by stump removal on severely diseased sites has been successfully demonstrated in British Columbia and Ontario. Trenching in a forest has also checked the secondary spread of the disease in limited situations. Long-term feasibility investigations to determine the cost effectiveness of stump removal in and around areas infected by Annosus and Armillaria root rots are in progress. (v) Biological control - Since these diseases are primarily subterranean, biological treatment will have to be systemic, selective, and economical, but not detrimental to beneficial fungi, such as mycorrhizal fungi. Investigations on biological control of root rots are still at a very preliminary stage, involving the use of a non-decay fungi with properties antagonistic to root decay fungi. The inhibitory properties of these fungi may cause direct lysis of the pathogen or produce metabolites toxic to the pathogen. Inoculation of freshly cut stumps with a fungus, Phlebiopsis gigantea, has been tried to prevent infection by Annosus root rot. Investigations are also being carried out to control Armillaria using "immunizing commensals," such as Ascocoryne sarcoides, Tympanis hypopodia, and bacteria (Dumas 1988, personal communication). Another approach designed specifically for the control of Armillaria is aimed at introducing inhibitory organism(s) into the soil of containerized seedlings. These organisms become established in soil and provide protection against infection when the seedlings are outplanted. (vi) Genetic selection - Investigations on genetic selection for improved resistance are being conducted to screen and develop provenances of white spruce, Norway spruce and lodgepole pine with resistance to Armillaria and Annosus root rots. (vii) Pathogen species identification - Proper identification of a disease and its causal organism is a prerequisite for control. Armillaria root rot has long been attributed to a fungus, Armillaria mellea (Vahl ex Fr.) Kummer. It has recently been discovered that the fungus is a complex of several species and biological forms, including A. obscura, A. ostoyea, A. mellea (Anderson and Ulrich 1979; Anderson 1986; Morrison et al. 1985a,b; Bérubé and Dessureault 1988, 1989; Blenis et al. 1988; Dumas 1988). Further work on determining the pathogenicity and impact of these species and biological forms is in progress so that eventually the distribution of forms or species that pose serious threat to certain host species can be determined, and then we may be able to develop some kind of hazard zones. Such information can also be used for predicting the impact of the fungal species and thus assisting in making certain recommendations for control.

Hudak and Singh (1970), Hudak and Wells (1974), and Singh (1980) reported that since Armillaria increases the mortality and decadence of natural stands damaged by insect infestations, early salvage and utilization of the insectdamaged trees be recommended to reduce losses.

Wallis (1976), and Morrison et al.(1988) made the following recommendations for managing Phellinus root rot and reducing losses in the forests of British Columbia: (i) Removal of infected stumps wherever possible at the regeneration phase, and planting of less susceptible tree species in and around the disease centres. (ii) When replacing the second-growth stands, clearing of the alder is recommended. However, where such an operation is not possible, plant the infection centers and some of their surrounding areas with a deciduous species; western red-cedar or a pine may also be recommended but the choice is dictated by site conditions; these species are known for their resistance to this disease. (iii) Pre-commercial thinning is recommended only where disease centers are less than 10 trees in size and are widely scattered; extracting colonized roots and stumps from the soil is also recommended in such situations. To discourage the spread of the disease, leave species which are more resistant than Douglas-fir as crop trees in and around the root rot centers when thinning and spacing are done in stands with few infection centers. Cutting or chemically killing trees in disease centers plus a four-trees-wide strip should effectively delay the spread of the root rot. (iv) During commercial thinning, if a major portion of the increment is being lost to root rot, clear-cut the stand or undertake salvage thinning operations, maximizing the number of trees removed at each salvage. Thin heavily infected stands only when selection of the final crop can be from species more resistant than Douglas-fir.

Bloomberg (1983a, 1983b, 1987) and Bloomberg et al. $(1980 \mathrm{a}, \mathrm{b})$ made a major breakthrough and recommended the use of a simulation model for predicting the spread and impact of Phellinus weirii root rot.

\section{White Pine Blister Rust}

\section{Disease Problem}

Blister rust of white pine is a perennial disease of stem and branches that has been of considerable concern to foresters and of great interest to forest pathologists in the past few decades. The disease is caused by a basidiomycetous fungus, Cronartium ribicola J.C. Fischer, which is a heteroecious rust fungus completing its life cycle on two different host species, pines (eastern white pine, Pinus strobus L.; western white pine, $P$. monticola Dougl.) and several Ribes species. Blister rust is known to cause an annual loss of over 0.6 million $\mathrm{m}^{3}$ (Anonymous 1979). Historically the disease is believed to be partly responsible for the destruction or near elimination of white pine in some parts of eastern Canada.

\section{Research and Management Strategies}

Research in Forestry Canada establishments in Quebec, Ontario and British Columbia has led to the development of a few strategies for the management of white pine blister rust.

Lavallée $(1974,1986)$ found that blister rust canker incidence in eastern white pine in Quebec was correlated with moisture and temperature conditions, and based on elevation and climate he suggested the existence of hostsusceptibility zones in Quebec. For example, in Zone 1, less 
than $5 \%$ of the white pine stems were infected even without Ribes eradication, and in Zone 2, the level of infection remained lower than $15 \%$ in most plantations. On the bases of these zones, recommendations can be made concerning the selection of site and choice of protective measures. In 1986 Lavallée recommended planting of eastern white pine only on healthy or less hazardous sites.

Hunt (1982, 1983a) believed that in British Columbia, all sites can be damaged by blister rust when trees are young; apparently stands on slopes are more prone to damage throughout the rotation. Accordingly, he recommended that susceptible pines should not be planted on steep slopes and that natural infection on steep slopes should be monitored and evaluated for blister rust damage. Hunt (1983a) also recommended that removal of lower branches from young western pine trees greatly reduces the possibility of stem infection and thus prevents the spread of the disease. When western white pine occurs as a component of a mixed stand, and when the trees are 2.5 to $5.0 \mathrm{~m}$ tall, all diseased branches up to $1.25 \mathrm{~m}$ or higher should be removed. However, when young growth of western white pine is the major component of a plantation, two such treatments are recommended. The first branch removal should be up to a height of $1.25 \mathrm{~m}$ when the trees are about $2.5 \mathrm{~m}$ tall, and additional diseased branches above this height may also removed. The second branch removal should be to a height of $2.5 \mathrm{~m}$ when the trees are about $4 \mathrm{~m}$ tall; again one may remove additional infected branches above this height. In both cases, trees with stem cankers or resinous patches on the stem should be removed. This treatment can usually be incorporated with thinning operation.

For ornamental pines, Hunt (1983a) recommended pruning as the most practical control strategy. Branches should be examined in spring and when the orange aeciospores become conspicuous, the infected branches should be pruned well beyond the canker margin.

Hunt and von Rudloff (1977) reported that since western white pine is highly variable and adaptable to a wide range of sites, resistant trees from widely separated areas can be used as parents for seeding new areas.

Hunt and Ilnytzky (1979) tried a few systemic fungicides (Bravo 54E, Topsin 50W, Plantvax 75W, Vitavex 75W, Cela W524, 20E, Cercobin 70W, Benlate 50W, and BAS 317F) to control blister rust on white pine trees that were 2 to $8 \mathrm{~m}$ high and less than 20 years old; none of these fungicides were effective enough to be commercially feasible.

In 1984 a collaborative research program between the Canadian Forestry Service and the British Columbia Ministry of Forests was initiated to select or develop resistance in genetically improved western white pine (Pinus monticola Dougl.). The program consists of selecting rust-free trees in heavily rust-infected stands, and collecting seeds for subsequent testing of the progeny with the rust inoculations.

Hunt (1983a,b) also recommended an integrated approach for managing this disease, including the use of fungicides, resistant trees, hazard rating, and branch removal. He believes that disease incidence can be minimized by - (i) planting resistant trees on flat sites where a cover has been left over creeks; (ii) growing western white pine more than $40 \mathrm{~m}$ away from creeks; (iii) discouraging open spaces which might favor Ribes growth and wherever possible eradicating Ribes during weed control operations; (iv) having slash fires in areas adjacent to young western white pine in early fall rather than spring, as smoke is known to reduce infection by killing basidiospores; and (v) removing branches following the prescriptions given in the preceding paragraphs.

\section{Western Gall Rust of Hard Pines \\ Disease Problem}

Western gall rust of hard pines, caused by Endocronartium harknessii (J.P. Moore) Y. Hiratsuka, [ = Peridermium harknessii J.P. Moore], is distributed throughout the natural range of lodgepole pine and jack pine in North America. It is found across Canada from Nova Scotia to Yukon, and infects jack pine, lodgepole pine and ponderosa pine in plantations, tree farms and tree nurseries (Hiratsuka 1987). Ziller (1974) reported that it is the most common and destructive stem rust of hard pines in western Canada. Hiratsuka (1987) believed that the disease intensifies in highly managed young pine forests, where the main stem galls girdle and kill small trees. The small active galls on the stem keep on increasing annually in size and induce reduction in tree growth and deformation for many years without killing the trees. They also reduce the lumber quality and making it unsuitable for commercial use. Sutherland and van Eerden (1980), however, reported that the disease does not kill seedlings in forest nurseries of British Columbia, and the losses so far have been inconsequential.

\section{Research and Management Strategies}

(a) Mechanical management - Hiratsuka and Powell (1976) recommended mechanical removal of rust galls and the use of protectant chemical sprays on susceptible hosts. (b) Search for Resistance - Allen and Hiratsuka (1985), after successfully inoculating young seedlings of lodgepole pine with Endocronartium harknessii, used the characteristic earliest symptoms for screening seedlings for relative resistance to western gall rust. Such a use of young plant material allowed testing for resistance in a much shorter time and under controlled conditions. The wide range of host response suggested that there are different degrees of resistance to western gall rust in lodgepole pine populations. In 1986 Allen suggested that the technology of clonal propagation of conifers may be useful in developing rapid and relatively inexpensive screening tests in a breeding program for resistance. In 1987 Allen and Hiratsuka, and in 1988 Allen, Blenis and Hiratsuka succeeded in obtaining axenic culture of $E$. harknessii from infected lodgepole pine gall tissue.

According to Hiratsuka (personal communication), biotechnological investigations are currently being conducted to understand the mechanism of host-parasite relationship and eventually develop varieties of jack pine that are resistant to E. harknessii.

(c) Search for Biological Control - In late 1970s and early 1980 s investigations were conducted to determine alternative means of controlling the western gall rust, that is, through the use of naturally occurring fungal pathogens. Sutton (1973), Tsuneda and Hiratsuka (1979, 1981), and Tsuneda et al. (1979) reported several hyphomycetous mycoparasitic fungi (such as Cladosporium gallicola Sutton and Scytalidium uredinicola Kuhlman) from the sori of Endocronartium harknessii. The former (C. gallicola) is an aggressive mycoparasite capable of growing over the rust 
galls very rapidly, causing substantial loss of the inoculum potential of the rust. It does not produce any antibiotic, but parasitizes the viable rust spores, quickly digesting the host cytoplasm. On the other hand, Scytalidium uredinicola slowly but steadily inactivates the entire gall. In 1979 Tsuneda $e t$ $a l$. investigated the potential of Scytalidium uredinicola to reduce the inoculum of Endocronartium harknessii. They found that the fungus disintegrated the rust spores and the basal cell region of the active rust sori within 48 to 72 hours. Hyphae of $S$. uredinicola also penetrated the woody tissue of the galls and destroyed the rust hyphae. These findings showed the potential of $S$. uredinicola in the biological control of E. harknessii. Tsuneda et al. (1980) further reported that $S$. uredinicola also produces a soluble metabolite, known as maltol, which inhibits spore germination and causes spore lysis in situ. Hodge and Nelson (1961) had earlier reported extraction of maltol from the bark and needles of conifers. Cunningham (1986) reported that treatment of 12 week-old pine seedlings with maltol reduced rust infection by $40 \%$. Blenis et al. (1988) confirmed the findings of Cunningham and investigated the mechanism of uptake and translocation of maltol. Fairbairn et al. (1983) compared the ability of four strains of Scytalidium album and $S$. uredinocola to inhibit the germination of $E$. harknessii spores on five different media. They reported that $S$. album produced a fraction with molecular weight greater than 10,000 and which caused lysis of the rust spores. However, two strains of $S$. uredinicola produced a chloroform-extractable material with a molecular weight of less than 10,000 , and which inhibited germination of $E$. harknessii spores. In 1980 Tsuneda and Hiratsuka also reported the destructive potential and parasitic process of Monocillium nordinii on Endocronartium harknessii. The metabolites produced by this parasite $(M$. nordinii) included the known compound monorden $\left(\mathrm{C}_{18} \mathrm{H}_{17} \mathrm{O}_{6} \mathrm{Cl}\right)$ and five new substances, including monocillin I, which showed pronounced activity against a variety of fungi, including $E$. harknessii. Recently Hiratsuka and his associates (1991, personal communication) initiated investigations to determine the possibility of using an insect vector to carry a mycoparasite to control the gall rust.

On the basis of the above work, it is believed that application of Cladosporium gallicola, Monocillium nordinii, Scytalidium uredinicola or their products on the rust galls, especially before the dispersal of rust spores, may be effective to inhibit the development and spread of $E$. harknessii. However, there is a need to investigate the mass production of spores of these mycoparasites or their products, enhance their activities, and determine the method and timing of application.

\section{Scleroderris Canker \\ Disease Problem}

Scleroderris canker, caused by Gremmeniella abietinia (Lagerb.) Morelet, has been recorded in every Canadian province except Prince Edward Island, Manitoba and Saskatchewan. So far the disease has been of greatest concern in Quebec, Ontario, New Brunswick and Newfoundland. It has been found on several species of pine, but has also been recorded on several other softwood species, such as Norway spruce, black spruce, white spruce, tamarack, European larch, Japanese larch, and balsam fir (FIDS 1968, 1981-88).
The pathogen is known to have races, of which two, the North American and the European, are well known. They are currently differentiated through serology (Dorworth 1981, Dorworth and Krywienczyk 1975, Dorworth et al. 1982) and gel electrophoresis (Ouellette et al. 1988, Petrini et al. 1989). The North American race is widely distributed in Canada and has been a problem in many tree nurseries and young plantations in eastern Canada since its first record in Quebec in 1964 (Smerlis 1967). The disease is most damaging on red pine, although jack and Scots pines are also affected quite severely in some locations. It often kills young trees during their first few years of growth, but once the trees are about $2 \mathrm{~m}$ high, they are relatively safe from the lethal attack of this fungus. In western Canada, where lodgepole, ponderosa and whitebark pines are the principal hosts, the disease has been recorded from a few scattered locations in Alberta (Hiratsuka 1987) and British Columbia (Funk 1981) with no significant damage. The European race is not as widely distributed, but is more damaging than the North American race, and is known to kill large pine trees. Since its first record in Canada from New Brunswick, the European race has been detected at several locations there, and in Newfoundland, Quebec and Ontario. In Newfoundland, the pathogen was generally found in small scattered patches, except in 1979 when it erupted in a small pine plantation and destroyed nearly all the red pine trees (Hudak and Singh 1983). In all these situations the infected trees were destroyed by roguing and burning. In Quebec, scleroderris canker has been most devastating, having been recorded from 697 out of 4784 red and Scots pine plantations in the southwestern part of the province (Laflamme 1987, personal communication); the European race was recorded in 395 plantations. In Ontario, the European race has been recorded from only four locations (FIDS 1986-1988), and in all cases the diseased trees were destroyed.

The disease is of considerable interest to Christmas tree growers and the Plant Quarantine Division of Agriculture Canada because Scots pine, a popular Christmas tree in eastern Canada and the United States, and Sitka spruce, an important commercial species in British Columbia, are some of the susceptible hosts.

\section{Research and Management Strategies}

Of the several methods researched, some are recommended for the prevention or control of the disease in tree nurseries and young plantations in Ontario, Quebec, New Brunswick and Newfoundland. Most of the recommendations, given below, are well enunciated in an information leaflet (LFC-3) by Laflamme (1991):

(a) In tree nurseries - (i) Nursery stock should be produced in areas where the disease is absent (Skilling $e t$ al. 1979). The first preventive measure for existing nurseries is elimination of the infection source around the nursery or a production area, such as hedges or plantations of infected pines. It is recommended that similar measures also be taken before establishing a softwood nursery in any area. Removal and destruction of infected seedlings prior to lifting is also known to considerably reduce the potential source of infection for a future plantation (Whitney, et al. (1983). (ii) Avoid low terrain and areas where large accumulations of snow melt in the spring. (iii) Fungicides are used in tree nurseries to reduce damage and prevent further spread of the disease. 
Sprays with Daconil 2787 Flowable, a mixture of Actidione TGF and Daconil 2787 wettable powder, Chlorothalinol, Maneb or Ziram have been tried with considerable success to prevent, reduce or control the North American race in tree nurseries in Ontario and Quebec (Smerlis 1983). Chlorothalinol is registered for the prevention of seedling infection in nurseries in the United States. Smerlis recommended that the disease on red and jack pine seedlings can be controlled with two applications, at a two-week interval, of $2 \%$ $(20 \mathrm{~g} / \mathrm{L})$ water suspension of Daconil 2787, a flowable fungicide, particularly when the first treatment is carried out early in the spring when the current year leaders are $5 \mathrm{~cm}$ (in red pine) to $10 \mathrm{~cm}$ (in jack pine) long. Also effective was a water suspension composed of $0.04 \%(0.4 \mathrm{~g} / \mathrm{L})$ of Actidione TG and $0.4 \%(4 \mathrm{~g} / \mathrm{L})$ of Daconil 2787 wettable powder when applied four times at weekly intervals.

Smerlis (1983) also reported that the Quebec strain of $G$. abietina on spruce seedlings can be controlled with one application in July of a water suspension of $2 \%(20 \mathrm{~g} / \mathrm{L})$ of Bravo $6 \mathrm{~F}, 2 \%(20 \mathrm{~g} / \mathrm{L})$ of Daconil 2787 flowable, 3\% (30 g/L) of Daconil 2787 wettable powder, or 4\% (40 g/L) of Dyrene.

Currently the only fungicide approved against the Scleroderris canker in Canada is Daconil ${ }^{\circledR} 2787$ W-75 (active ingredient: chlorothalonil), in concentrations of 2.3 or $4.7 \mathrm{~kg}$ per $1000 \mathrm{~L}$ of water, depending on whether a sprayer or a fogger is used. This product should be applied in the spring before new shoots appear, every two or three weeks until July, and then every four weeks until September. Although two applications of higher concentrations of this product $(20 \mathrm{~kg} / 1000 \mathrm{~L})$ were successful, such concentrations were difficult to apply in normal operations (Smerlis 1983).

(b) In plantations - Dorworth (1976) recommended that timely detection and estimation of the severity of this disease in plantations is necessary to give forest managers an opportunity to decide if and when any control measure is needed. Effective and timely regulatory action can also check or at least slow down the spread of the disease in many situations. By prohibiting the movement of Christmas trees and nursery stock from the infected areas, spread of Scleroderris canker can be prevented.

For planting, select only species and sites that are not susceptible to the disease. The North American strain can best be controlled by planting disease-free stock in areas where no infection has been observed. Nearby plantations should be examined and monitored for the disease, and if needed, a proper sanitation treatment should be applied. After planting, detection and monitoring of the disease are imperative.

Considerable success has also been achieved in controlling the severity and spread of this disease by silvicultural means, such as pruning and clipping of lower infected branches, that is, at least a third of lower whorls. (Laflamme 1988, 1991; Laflamme and Blais 1988). The purpose of this treatment is to remove diseased branches, whether or not symptoms are apparent, thus decreasing the amount of the inoculum, and to remove those healthy branches which are most likely to become infected. The pruned branches may be left on the forest floor, provided there is a space of more than $60 \mathrm{~cm}$ between the remaining lowest branches and the forest floor, failing which the pruned branches should be destroyed. Control is most effective when infection is less than $20 \%$; in plantations with infections as high as $76 \%$ the disease can be reduced by clipping residual infected branches in the following years. If the disease is concentrated in one section of the plantation, pruning may be done only in this area, thus decreasing the cost of treatment. All dead and dying trees (with more than two-thirds of the whorls affected) should be cut and debranched.

Successful eradication of the much more destructive European race of the pathogen was accomplished by the destruction of infected trees in Newfoundland (Singh et al. 1980), and in New Brunswick and Ontario (FIDS 1971, 1984-89).

Some softwood species with more resistance than red pine have been recommended for use in several areas (Whitney et al. 1983). Provenances of jack pine have been found that are resistant to the North American strain. A few Scots pine selections and certain white pines, and varieties of spruce have also shown resistance to the European strain (Skilling et al. 1979).

\section{Dwarf Mistletoe \\ Disease Problem}

Dwarf mistletoes, Arceuthobium spp. (Family Viscaceae), belong to a group of flowering plants that are parasitic on a wide variety of conifers in North America. Van Sickle and Smith (1978) reported that in Canada there are five species of dwarf mistletoes, that are widely distributed on economically important tree species. These include lodgepole pine dwarf mistletoe [Arceuthobium americanum Nutt. ex Engelm.]; hemlock dwarf mistletoe [ $A$. tsugense (Rosendahl) G.N. Jones] - two races; larch dwarf mistletoe [A. laricis (Piper) St. John]; Douglas-fir dwarf mistletoe [A. douglasii Engelm.]; and eastern dwarf mistletoe [ $A$. pusillum Peck.]. Dwarf mistletoes attack their hosts in all age classes, causing mortality or loss of vigor, growth and wood quality (Baranyay and Smith 1972, Van Sickle and Wegwitz 1978). Mortality varies, but losses are often considerable. Growth losses vary with species, stand age, and with site. National estimates of losses in growth induced by dwarf mistletoes were 4.7 million $\mathrm{m}^{3}$ in 1976 and 3.8 million $\mathrm{m}^{3}$ in 1981 (Table 3).

\section{Research and Management Strategies}

The importance of dwarf mistletoes and the effectiveness of past surveys, research and technology transfer are manifested in a relatively high level of control activity, and in the development of guidelines for prevention and management of the parasites. It is estimated that losses from mistletoes could be reduced by $50 \%$ to $80 \%$ over the next crop rotation.

Dwarf mistletoes are relatively easier and more convenient to control or manage because of easier detection, relatively narrow host range, and limited and slow rate of spread. Generally speaking, measures to prevent or control these parasites consist of better management practices, including cutting or burning individually affected trees, or clear cutting the entire infected stand. However, Baranyay and Smith (1972) remarked that due to variable incidence of the infection, it is not possible to provide an overall control for all conditions. The most suitable decision for each case depends on stand composition, stand age, number of years to harvest, incidence, pattern and length of time the stand has been infected. Complete eradication of the parasite may be 
possible if effective preventive measures can be applied during or shortly after clear-cutting. Where preventive measures are not applied successfully, infection can be reduced in young stands by sanitation to a level at which there is little growth and spread of the parasite. If properly controlled during the first rotation, dwarf mistletoe should not be a problem in subsequent rotations.

\section{Biological and Chemical Control}

Anonymous (1968) and Baranyay and Smith (1972) reported that the possibility of controlling dwarf mistletoes with biological agents has been researched, but with no development of a practical control strategy. Some fungal pathogens [Wallrothiella arceulthobii (Pk.) Sacc., Septogloeum gillii Ellis, and Colletotrichum gloeosporioides Penz. sensu von Arx] of the aerial shoots of dwarf mistletoes on lodgepole and jack pines have been reported from British Columbia, Alberta and Saskatchewan, and are known to restrict the development of the vegetative and reproductive shoots of the parasite. Similarly several canker fungi, known to be parasitic on a few dwarf mistletoes, are also being investigated.

Baranyay and Smith (1972) also reported that considerable work has been done on the development of chemicals to control dwarf mistletoes, but so far no material has been developed to make commercial use feasible.

\section{Silvicultural Control}

Baranyay (1970), Baranyay and Smith (1972), and Van Sickle and Wegwitz (1978) reported that silvicultural methods are the least expensive and the most effective measures to control dwarf mistletoe in lodgepole pine regenerations. These include eradication of infected trees during or after logging or fire from areas designated for regeneration. They also recommended that all infected stands be monitored for sanitation or salvage operations. Depending on stand age, disease intensity and pattern, duration of infection, and length of time to harvest, silvicultural methods usually involve the following procedures (Baranyay and Smith 1972 and Van Sickle and Wegwitz 1978):

(a) Prevention - (i) Cut layout - This is the initial and most plausible strategy to prevent establishment of the parasite in a regeneration. Since the first opportunity for prevention exists during the preparation of cutting plans, partial cutting should not be allowed in infected stands. To avoid re-invasion of the disease, clear-cut borders should be located along artificial barriers to mistletoe such as road and powerline rights-of-way, and healthy stands, including stands of resistant coniferous and immune broadleaf species, should be demarkated. The latter often form effective barriers along rivers and around lakes and bogs. Strip cutting or small clearcuts are justified only if the regeneration of a resistant species is ensured.

(ii) Elimination of infected residuals - Infected residual trees or infected advanced regeneration are major source of infection in new stands. During or shortly after clear-cutting, infected residuals and susceptible advanced regeneration should be removed otherwise dwarf mistletoe infections on these trees become reproductively active, produce seed, and infect regeneration as soon as the latter becomes established. Therefore elimination of dwarf mistletoe seed sources should be practised during or immediately following logging (Van
Sickle and Smith 1978). Van Sickle and Wegwitz (1978) also reported that the inability to eliminate dwarf mistletoe from young lodgepole pine stands, even with three successive sanitation treatments, emphasizes the importance of control efforts during stand harvest and second crop establishment, which effectively minimizes the possibility of infection of future stands. They believe that although silvicultural treatment of the vast backlog of dwarf mistletoe-infected lodgepole pine is needed, efforts should be concentrated on the younger stands because the frequency and intensity of mistletoe infection increase with stand age and suppressed growth rates. Long-term monitoring of the disease will be needed, along with growth rates to eventually evaluate the usefulness of the silvicultural treatments.

Fire is known to effectively remove non-merchantable infected material. Broadcast slash burning is recommended, but areas with dwarf mistletoe-infected original stands should be given priority for slash burning (Van Sickle and Wegwitz 1978).

Where terrain permits, a drag scarifier or drum chopper can be effectively used to destroy infected residuals and infected advanced regeneration. Where terrain is unfavorable or where wet conditions prevail, manual elimination of dwarf mistletoe seed sources after logging may be necessary (Van Sickle and Wegwitz 1978).

After the cutover area is cleared of infected residuals, the establishment of a $37-\mathrm{m}$ wide barrier strip along bordering infected stands is recommended to prevent or reduce the rate of re-invasion. This can be done by planting resistant species before the susceptible regeneration becomes established (Van Sickle and Wegwitz 1978).

(iii) Species manipulation - Van Sickle and Wegwitz (1978) also recommended that an effective means of reducing future infection is to promote higher participation of mistletoe-resistant species in future stands. This is possible in the following combinations: lodgepole pine - Douglasfir; lodgepole pine - spruce; western larch - Douglas-fir hemlock; Douglas-fir - ponderosa pine.

Species manipulation can also be achieved by logging an infected overstory with care to preserve the existing immune regeneration. Where immune regeneration is sparse or lacking, seed trees of immune tree species should be left after harvesting.

(b) Sanitation - If acceptable yields are to be obtained from heavily infected stands, they must be treated. During sanitation, old-infected residual trees, groups of trees, or infected bordering stands should be cut first. Young trees with stem infections should be removed and destroyed; those with branch infections can also be removed or, if practical, pruned. Dwarf mistletoe can be eliminated by pruning branches less than $5 \mathrm{~cm}$ in diameter if aerial shoots do not occur within $10 \mathrm{~cm}$ of the stem (Hawksworth and Johnson 1961).

Van Sickle and Smith (1978) remarked that sanitation is most effective when trees are small; therefore, the age at which fast-growing trees can be effectively sanitized is lower than for slow-growing trees. Sanitation of infected stands can be combined with juvenile spacing at little extra cost. One or two treatments at three-year intervals are generally necessary to achieve success. In heavily infected stands older than 25 years, sanitation is justified only if fewer than half of the dominant and codominant trees are infected. Opening up the 
stand may stimulate dwarf mistletoe seed production on previously shaded infections.

(c) Salvage - In stands over 40 years of age, sanitation is difficult and unreliable because dense crowns obscure branch infection. Lightly infected stands are best held for logging to rotation age as growth loss will be light. Intermediate cuttings in these stands should be avoided as they increase disease intensity in the overstory and promote the establishment of regeneration, which later becomes infected. Early removal of such stands is recommended to get the land back into maximum production (Van Sickle and Smith 1978).

\section{Dutch Elm Disease \\ Disease Problem}

Dutch elm disease (DED), caused by Ophiostoma ulmi (Buis.) Nannf. [ = Cerotocystis ulmi (Buism.) C. Moreau], has been one of the most destructive tree diseases in both forest and urban environments. It has caused extensive tree mortality in North America, and will probably continue to be a serious problem in areas where elm is grown. Few if any pests have had a similar impact on shade tree populations in urban areas. The disease has also affected the economy of areas where elm is a valuable timber-producing species.

Since its first record in Quebec in 1944, the disease has spread over an area stretching from the Atlantic ocean (excluding Newfoundland) to southern Manitoba. In 1981 the disease was also confirmed on a tree in Regina, Saskatchewan. The disease is known to affect all native species of elm, including white, red and rock elm. It has been of greatest concern in Manitoba, Ontario, Quebec, New Brunswick and Nova Scotia.

DED is known to kill trees of all ages, but overmature, stressed or weakened trees attract beetles [Hylurgopinus rufipes (Eichh.) and Scolytus multistriatus (Marsh), which are known vectors of the fungus] more often than young, vigorously growing trees, and are more often killed by the disease. Since large, fully mature elm trees are valuable and highly regarded in urban situations, farm shelter belts, and natural stands, mortality of these trees by DED remains a major concern.

\section{Research and Management Strategies}

(a) Search for Reduced Virulence or Increased Resistance - Dutch elm disease is one of the most extensively researched tree diseases in Canada. Considerable knowledge has been accumulated during the past three decades on several aspects of the disease, including pathogenicity of the fungus; production, isolation, characterization of toxin, Cerato-ulmin (CU); host-parasite relationship; biochemical genetics of virulence of the pathogen; and mechanism of host resistance. The ultimate objective of all these investigations has been to obtain a better understanding of the pathogenicity of the fungus and the host reaction, so as to induce or increase resistance to the disease or reduce the virulence of the pathogen.

Over the years, Hubbes and associates have done extensive work on the biochemistry and genetics of the pathogen, $O$. ulmi, and host-pathogen relationship with the ultimate objective of inducing resistance in the host or controlling the virulence of the pathogen (Bernier et al. 1983; Jeng 1986;
Jeng and Hubbes 1983; Hubbes 1987a,b; Hubbes and Jeng 1981; Jeng et al. 1983; Dumas et al. 1983; Duchesne et al. 1985, 1986; Svircev et al. 1988). Frontier technology is being applied to understand the aggressive and nonaggressive behavior of different isolates of the fungus, and the response of different host species. It is now possible to differentiate species and subspecies of the pathogen, and the resistant and susceptible varieties of the host through the use of biochemical markers, such as isozymes and protein patterns (Jeng and Hubbes 1983; Jeng 1986; Hubbes 1987a). Thirty-six proteins have been found specific for a nonaggressive and 12 for an aggressive strain of the fungus. A correlation between amino acid utilization and pathogenicity among strains of $O$. ulmi has also been discovered. Investigations on the mechanism of resistance have shown that conditioning inoculation with a non-aggressive strain of $C$. ulmi rendered white elm seedlings resistant to further attack by an aggressive strain of the same pathogen (Hubbes and Jeng 1981; Hubbes, 1981, 1986, and 1987b). This is an extremely promising development for inducing resistance in a host (Hubbes 1981, 1986, and 1987a, b, c).

Another aspect being investigated is that of recombinants and mutants. Development of a virulent mutant and its gene mapping will lead to gene manipulation and eventual control of the gene(s) of virulence (Bernier and Hubbes 1990). Investigations are also being continued on the process of inhibition by recently identified mansonones (ACDEF) and their role in inducing resistance in the host through the use of cell and tissue culture (Dumas et al. 1983; Duchesne et al. 1985, 1986; Jeng et al. 1983; Hubbes 1981, 1986, and 1987a, b, c).

The toxin, cerato-ulmin (CU), has been isolated, purified and characterized, and details of its action on host tissue has been investigated (Takai 1973, 1978; Richard and Takai 1973, 1984; Hiratsuka and Takai 1981; Krywienczyk et al. 1979; Takai et al. 1980; Takai and Richard 1972, 1978; Stevenson et al. 1979; Ouellette 1978a,b,c, and 1980; Stevenson and Takai 1981). Apparently CU production is closely related to pathogenicity. Cerato-ulmin production by $O$. ulmi strains and $\mathrm{F}_{1}$ progenies has been evaluated, and crossing between aggressive and non-aggressive parents has resulted in breaking this pattern at random (Krywienczyk et al. 1979). Monoclonal antibodies, developed from doublestranded RNA from $O$. ulmi, are being used for obtaining a better understanding of the host-parasite interactions. The role and mode of action of the toxin, including the diffusion of a phytotoxic glycopeptide in pathogen cells and in infected young elm seedlings, are being evaluated by immunohistochemical and immuno-cytochemical techniques and by a protein-A gold labelling method (Benhamou et al. 1985a,b; Ouellette and Benhamou 1986).

(b) Maintain the health and vigor of the trees.

(c) Remove dying and recently killed elm trees, because they may be the source of new generations of the funguscarrying beetles.

(d) For individual trees of high ornamental value, the use of fungicide injections into root systems has generally proven to be quite effective in controlling the disease, and it is believed that the treatment is cost effective. Stillwell et al. (1973) showed the potential of some antibiotics, such as cryptosporiopsin, to control Dutch elm disease.

(e) Kondo (1982) recommended that high-value elms can be saved from Dutch elm disease with root-flare injections 
of benomyl and by sanitation. He discussed a successful program of managing this disease in urban conditions by using an integrated approach, called "Integrated System of Control." It included not only the integration of different methods of control (through the use of sanitation procedures, preventive insecticidal sprays, fungicidal injections to roots, and resistant species), but also an evaluation of this approach through cost-efficiency studies and by comparison with noncontrol areas. He enunciated four essential steps for establishing a successful Integrated System of Control of Dutch Elm Disease: 1) Analysis of basic data, 2) Exploitation of regional variations, 3) Identification of appropriate control methods, and 4) Integration of control methods. Through the efforts of the integrated program, elm losses were reduced to less than $5 \%$ by 1978 and to less than $1 \%$ in 1979 and 1980 in Sault Ste. Marie, Ontario. Kondo also emphasized that integration of control can only be properly instituted when the above four components are critically monitored and integrated. At the same time, it must be realized that an integrated DED control program developed for one region cannot be transplanted to another region. Control will have to be developed by continually monitoring the various appropriate control techniques for the beetles, and the fungus. The monitoring is essential to fine tuning of the program and must involve more than just monitoring the number of elms becoming infected with DED.

\section{Stem Decays}

\section{Disease and Damage Problem}

Basham (1991), in his latest contribution entitled "Stem decays in living trees in Ontario forests: A user's compendium and guide," discusses major decay problems, their impact, and management strategies. Most of the information in this text is obtained from this report.

Decays of the stems of living trees and the wood of dead trees are mostly caused by a group of Hymenomyceteous fungi, which cause considerable damage to both softwood and hardwood species.

Decays and deteriorations of trees are a major problem for Canadian forests and the timber industry; their incidence and intensity are variable among host species and are influenced by many factors, such as tree age, site conditions, stand history, growth rate, invasion by insect pests and disease pathogens. Decay fungi cause damage by degrading and metabolizing cell-wall substances, causing a progressive reduction in the strength of the invaded woody tissues. In the advanced stages of decay, all the damage is virtually in structural strength of the wood. Since decay attacks cell walls, pulp yield and quality are also reduced (Basham and Haig 1991). Broadly speaking, on the basis of their effects on wood, decays are of two types: white rots and brown rots. The white rots degrade lignin at a faster rate than cellulose, while the brown rots degrade only the cellulose and hemicellulose.

The losses are enormous, although in many cases they are cryptic. Stem decays cause losses in volume and product value. Overall losses to stem decays are difficult to quantify accurately, partly because of the internal nature of stem decay and the unreliability of external indicators.

\section{Research and Management Strategies}

Basham (1991) and Basham and Haig (1991) recommended that losses to stem decay can be prevented or minimized in individual trees by taking measures that can reduce competition and increase tree vigor; these include removal of trees with conks or large stem wounds, as well as trees with crooked or malformed trunks; by avoiding felling scars, broken tops, sunscald wounds, and fire scars; preventing or minimizing insect infestations; preventing or minimizing logging machinery wounds; and by pruning branches before they reach a diameter of $2 \mathrm{~cm}$. Since the prescriptions for various stands and plantations vary with different tree species and sites, the authors have made specific recommendations for different softwood and hardwood species. The authors have further recommended that the simplest means of combating stem decay is to harvest stands before they reach an age when decay may have a serious impact.

Basham and Haig (1991) also suggested that biological control of stem-decay fungi holds great promise for the future. It may be possible to inoculate young seedlings with fungi antagonistic to decay-inducing fungi, and let them spread systemically throughout the developing trees, protecting them throughout their rotation. A few promising results have been obtained with cryptosporiopsin, hyalodendrin, scytalidin, and a few other antibiotics of fungal origin, for the control of disease-causing fungi and some stains in wood chip piles.

Estimates of decays, deterioration and cull have been used in adjusting scaling regulations, salvage operations and salvage periods after tree death.

\section{Maple Declines \\ Disease Problem}

A dieback is characterized by a progressive dying back of a stem or a branch from the tip, and aggregation of these symptoms throughout the crown results in tree decline. Declines of hardwoods have been important pathological problems in Canada, since the 1950s. However, they have gained considerable prominence since 1982 .

Sugar maple in eastern Canada, particularly in Quebec, New Brunswick and some parts of Ontario is known to suffer from a group of stress-initiated diseases known as diebacks or declines. These diseases occur when trees, weakened or predisposed by adverse environmental factors, are invaded and sometimes killed by secondary organisms.

Surveys have shown that such declines and diebacks are common throughout maple bush bioclimatic zones. Although sugar maple remains the most frequently affected tree species, yellow birch, red oak, beech and various species of ash and black cherry are also affected and show similar symptoms, of crown dieback.

Houston et al. (1990) remarked that dieback/decline diseases of sugar maples epitomize the complex nature of tree diseases, for they reflect interactions of fungal pathogens and various stresses. The latter include defoliating insects, as well as adverse abiotic factors, such as atmospheric pollutants, or inclement weather conditions of unusual winter and drought. Their complex etiology also serves to emphasize the need for a holistic approach to managing sugarbush. They stated that the main objective of managing a sugarbush is to produce as much high-quality sap as possible over a sustained period. This is usually achieved by providing trees with optimum growing conditions and protecting them from any stress, and they recommended an integrated approach of managing these bushes. Early recognition of pest(s) or 
stress, an understanding of their potential effects, and a knowledge of how and when to deal with them are essential to the good and healthy management of a sugarbush. It is also recognized that many sugarbush problems result directly or indirectly from human activity. Every disturbance, including those resulting from forest management practices, may have significant consequences.

\section{Research and Management Strategies}

Houston et al. (1990) also believe that as the intensity of management increases, so do pest problems. Some general guidelines for managing a sugarbush are enunciated below: 1. Learn as much as possible about your sugarbush as a biological community.

2. Conduct operations to ensure adequate numbers, distri- bution, and growth of quality crop trees.

3. Understand the consequences of creating a pure stand of sugar maple.

4. Avoid wounding roots and stems, and compacting the soil.

5. Give trees time to recuperate from stress events.

6. Ensure that tapping is done properly. Carefully follow guidelines on the number of taps per tree in relation to different tree diameters, and also on how to place them on the tree.

7. Do not use paraformaldehyde.

8. Remove all spouts soon after the sap flow stops.

9. Watch for insect and disease pests.

10. Learn who the local experts are and contact them before problems become severe and unsolvable.

\section{Frais d'adhésion 1992-1993}

\section{Membre actif}

Première et deuxième année suivant la graduation (graduation de 1991 et de 1992)*(2.49\$ de T.P.S. inclus)

Marié ou équivalent

Deuxième adhésion seulement $*(2.49 \$$ de T.P.S. inclus $)$

Tout autre membre actif $*(2.49 \$$ de T.P.S. inclus $)$

\section{Autres catégories de membres}

Membre à la retraite (afin d'obtenir le statut de membre à la retraite, ce dernier doit être membre de l'Institut depuis quinze ans)

*(2.49 $\$$ de T.P.S. inclus)

Membre étudiant $*(1.31 \$$ de T.P.S. inclus)

Suite à une demande écrite, le conjoint d'un membre actif peut obtenir une réduction de ses frais d'adhésion en fonction d'un montant déterminé annuellement. Les membres conjoints sont membres d'une même section, demeurent ensemble en tant que conjoints et utilisent la même adresse postale.

L'année budgétaire de l'Institut débute le ler juillet pour se terminer le 30 juin. Les demandes d'adhésion effectuées après le ler janvier 1992, seront facturées à la moitié des frais d'adhésion de l'Institut pour l'année en cours. Aucun frais d'adhésion ne sera facturé au membre soumettant une demande après le ler avril pour la durée de l'année en cours.

Le frais de section s'additionnent à ce montant et varient de $5.00 \$$ à $30.00 \$$ pour l'année budgetaire de l'Institut.

*N.B.: La portion des frais d'adhésion couvrant les frais du Forestry Chronicle est assujettie à la T.P.S. Pour les fins de la taxe, ce coût est calculé sur une base de 38.00 \$ et correspond à 2.49 \$ de T.P.S. (sauf pour le taux étudiant de 20.00 \$, soit 1.31 \$ de T.P.S.) 